\begin{tabular}{|c|c|c|}
\hline \multirow{3}{*}{ 年T } & International Journal of Agriculture and Wildlife & $\sqrt{5}-\frac{9}{2}$ \\
\hline & Science & 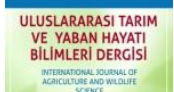 \\
\hline & http://dergipark.org.tr/ijaws & \\
\hline
\end{tabular}

Araştırma Makalesi

\title{
Pomological and Chemical Attributes of Almond Genotypes Selected from Hatay Province
}

\author{
Ahmet Sümbül ${ }^{*}, \quad$ Safder Bayazit ${ }^{2}$ \\ ${ }^{1}$ Sivas Cumhuriyet University, Suşehri Timur Karabal Vocational School, Department of Plant and Animal Production, \\ Suşehri/Sivas \\ ${ }^{2}$ Hatay Mustafa Kemal University, Faculty of Agriculture, Department of Horticulture, Hatay
}

Received: 25.06.2018 Accepted: 05.10.2018

\section{Keywords:}

Prunus dulcis Mill., protein content, total oil, kernel ratio

*Corresponding author asumbul3188@gmail.com

\begin{abstract}
This study was conducted to determine some pomological and chemical characteristics of 19 almond genotypes in term of found to be promising in yield and quality attributes. Selected from natural almond populations of Hatay province and district (Belen, Antakya, Yayladağı, Altınözü, Hassa) and shelled fruit weights of selected promising genotypes varied between $1.55 \mathrm{~g}$ (HTY-28) - $6.34 \mathrm{~g}$ (HTY-67); kernel weights varied between $0.61 \mathrm{~g}$ (HTY-25) - $1.29 \mathrm{~g}$ (HTY-67); kernel ratios varied between 15.99\% (HTY-17) - 50.46\% (HTY-28); double-kernel ratios varied between $0.00 \%-16.67 \%$; empty fruit ratios varied between $0.00 \%$ - 13.33\%; total oil contents varied between $44.65 \%$ (HTY-40) 54.56\% (HTY-14); protein contents varied between 19.59\% (HTY-27) - 33.79\% (HTY-57).
\end{abstract}

\section{Hatay İlinden Seçilen Badem Gentoplerinin Pomolojik ve Kimyasal Özellikleri}

\section{Anahtar kelimeler:}

Prunus dulcis Mill., protein içeriği, toplam yağ, iç meyve oranı
Özet. Bu çalışma, Hatay ili ve ilçelerindeki (Belen, Antakya, Yayladağı, Altınözü, Hassa) doğal badem popülasyonlarından seçilen verim ve kalite özellikleri bakımından ümitvar bulunan 19 badem genotipinin bazı pomolojik ve kimyasal özellikleri belirlenmiştir. Seçilen ümitvar genotiplerin kabuklu meyve ağırlıkları $1.55 \mathrm{~g}$ (HTY-28) - $6.34 \mathrm{~g}$ (HTY-67); iç meyve ağırlıkları $0.61 \mathrm{~g}$ (HTY-25) - $1.29 \mathrm{~g}$ (HTY-67); iç meyve oranı \%15.99 (HTY-17) - \%50.46 (HTY-28); çift meyve oranı \%0,00 - \%16,67; boş meyve oranları \%0,00 \%13,33; toplam yağ içeriği \%44.65 (HTY-40) - \%54.56 (HTY-14); protein içerikleri \%19.59 (HTY-27) \%33.79 (HTY-57) arasında değişmiştir. 


\section{INTRODUCTION}

Almond belongs to Prunus genus of Rosaceae family. It has a natural widespread in India, Iran and Pakistan and spread in time from these countries to Mediterranean region. Almond botanically has a stone-fruit structure, but mesocarp dry-out at ripening period and fruits are considered as nut-fruits (Soylu, 2003).

Value of almond is always increasing since it is processed into various food stuff in food industry. Fruits are quite rich in protein, oils, fatty acids, vitamins and minerals, thus have several positive impacts on human health such as prevention of cholesterol and cardiovascular diseases. Previous studies on nut-fruits revealed that almond had the greatest protein content (20\%) and did not contain cholesterol (Ahrens et al., 2005).

Kernels are used as snacks year-long under proper preservation conditions. They are also used in candies, chocolates and pastry industry. Besides, kernels used in pharmaceutics, cosmetics and dye industries.

Almond is virtually a hot-climate fruit, thus is it grown almost in all regions of Turkey, except for highlands and cool and humid sections of Black Sea region since fruits requires high temperatures at ripening period. Winter dormant season is low in almonds and spring late-frosts are the most significant factors restricting almond growing in Turkey. Since almond is an early-blooming species, spring frosts can easily damage flowers, thus do not allow growers to get regular yields and constitute a significant factor in lagging of commercial almond growing. Therefore, orchards fully established with almond trees are scarcely any in Turkey. Almond trees are usually planted as border-line trees and growing is practices without any cultural practices (irrigation, fertilization, chemical applications, pruning) (Tosun, 2002).

Despite all these negative issues, there is an ever-increasing interest in almond growing since trees can grow stony and gravel soil conditions in which the other trees are not able to grow, fruits are served to markets early as unripe fresh almond, trees have early fruit set, fruits have quite long shelf life and high market value and trees are commonly used in forestation practices. Although almond trees have been grown as border trees along the field borders until recently, specialized almond orchards have started to be established in recent years because of high income generation potential of the fruits and farmer's consciousness about health benefits of almond.

Although specialized almond orchards have recently been established because of increasing significance and economic returns, almond trees in almost all regions of Turkey are seed-propagated trees. Since Turkey is quite rich in seed-propagated almond populations, there is a large variation in flowering periods as not the influenced from spring late frosts, resistance to pests and diseases, adaptation to various ecological conditions, tree and fruit quality attributes. Such a broad variation facilitates the works of breeders on almond selection. Thusly, most of the standard cultivars commonly grown worldwide were randomly selected from genotypes. Almond cultivars of Nonpareil, Texas, Ne Plus Ultra, IXL in the USA; Lauranne in France; Tuono, Genco, Cristomorto in Italy; Verdeal, Gama, Boa Casta in Portogul; Glorieta, Masbovera in Spain can be given as an example for these cultivars (Dokuzoguz et al., 1968; Noronha Vaz, 1996; Dicenta et al., 1999).

Almond selection studies were performed by researchers in different sections of Turkey (Dokuzoğuz et al., 1968; Dokuzoğuz and Gülcan, 1973; Kalyoncu, 1990; Cangi and Şen, 1991; Aslantaş, 1993; Bostan et al., 1995; Karadeniz et al., 1996; Şimşek, 1996; Gerçekçioğlu and Güneş, 1999; Balta, 2002; Ağlar, 2005; Yıldırım, 2007; Köse, 2013; Bozkurt, 2017). Late flowering, high yield and superior quality attributes were mostly focused on these selection studies and promising genotypes were identified.

Today, almond breeding programs usually focus on collection of gene sources, selection and assessment of genotypes and breeding of late-flowering and self-pollinating genotypes (Ağlar, 2005). Hatay province has dominant sub-tropical climate conditions, but has temperate climate in high and inner sections. Thus, early and late genotypes adapted to these climate conditions should be selected. In this study, some pomological and chemical quality attributes of 19 almond genotypes selected from Hatay province and town were investigated.

\section{MATERIAL AND METHOD}

\section{Plant Material}

This study was conducted in Antakya province and Altınözü, Belen, Hassa and Yayladağı towns of Hatay province of these district with intense seed-propagated almond populations at yield-ages between 2010-2012 years. A total of 73 almond genotypes were selected within the aim of this study. Selected genotypes were subjected to weighted ranking based on selection breeding criteria. The 19 genotypes with the greatest scores from weighted ranking were identified as promising genotypes. UPOV criteria were considered in weighted ranking (Kalyoncu, 1990; Aslantaş, 1993; Balta, 2002). 


\section{Pomological Analyses}

For each one of selected genotypes, 30 fruits were used for pomological analyses. As specified by Yıldırım et al. (2007), fruits were deshelled from green shells, kept at room temperature under shade for 2 weeks and finally dried in an oven $30^{\circ} \mathrm{C}$ for 24 hours for homogeneous drying. Then, relevant measurements and analyses were performed.

Shelled fruit and kernel weights were measured with a digital balance with a $\pm 0.01 \mathrm{~g}$ sensitive. Shelled fruit and kernel dimensions (width, length, height and shell thickness) were measured with a digital caliper \pm 0.01 $\mathrm{mm}$ sensitive. Kernel ratio and the ratio of kernel weight to shelled fruit weight were determined as percentage. Double kernel and empty fruit ratios were determined by breaking all the fruits of each replicate one by one.

Kernel bulkiness was determined by the number of kernels fitted into $1 \mathrm{onz}(28.3 \mathrm{~g})$ international standard and kernel size groups were determined accordingly. The size groups were specified as follows (Table 1) (Aslantaş, 1993; Şimşek, 1996).

Table 1. The number of kernels fruit placed in $1 \mathrm{onz}$ and kernel size group $(28.3 \mathrm{~g})$.

Çizelge 1.1 onz (28.3 g) içerisine giren iç badem sayısı ve büyüklük grubu.

\begin{tabular}{cc}
\hline Number of Kernel Fruits & Kernel Size Group \\
\hline $1 .>30$ & Small \\
2. $25-30$ & Medium \\
$3.20-25$ & Large \\
$4 .<20$ & Very large \\
\hline
\end{tabular}

In addition to subjective color classification (light - medium - dark), shelled fruit and kernel color was determined with the aid of a color-meter (Minolta CR-300). Color parameters of $L^{*}, a^{*}, b^{*}$, Chroma (C) and hue $\left(h^{\circ}\right)$ angle were measured. In color parameters, $L^{*}$ indicates the brightness of the color ( $L^{*} 0$ black, $L^{*} 100$ white), $a^{*}$ indicates color conversion from green to red (positive values indicating red and negative values indicating green), $b^{*}$ indicates color conversion from yellow to blue (positivevalues indicating yellow and negative values indicating blue), $C$ indicates color intensity and $h^{\circ}$ indicates angle value of the color ( 0 ; red-purple, $90^{\circ}$; yellow, 180'; blue-green, 270'; blue) (Zerbini and Polesollo, 1984).

\section{Chemical Analyses}

Total oil analysis was performed with the Soxholet method in accordance with Akyüz and Kaya (1992). Resultant values were expressed in percentages. Protein content was determined with Kjeldahl method by using \%N contents (1) (Kaçar, 1984).

$$
\% \text { Protein }=\% N \times 6.25
$$

\section{RESULTS AND DISCUSSION}

Shelled fruit weights of the selected genotypes varied between $1.55 \mathrm{~g}$ (HTY-28) and $6.34 \mathrm{~g}$ (HTY-67) with an average value of $4.13 \mathrm{~g}$ (Table 2). Present findings were similar with the results reported by earlier studies carried out in Turkey. Kalyoncu (1990) carried out a study around the reservoir of Konya Apa Dam and reported shelled fruit weights as between 3.37-5.24 g, Gerçekçioğlu and Güneş (1999), reported shelled fruit weights of the almond genotypes selected from Tokat province and surroundings as between $2.18 \mathrm{~g}-7.58 \mathrm{~g}$, Ağlar and Balta (2007) carried out a study in Pertek location and reported shelled fruit weights as between $3.91 \mathrm{~g}-8.99 \mathrm{~g}$, Köse (2013) reported shelled fruit weights of the almond genotypes selected from İspir town as between $2.17 \mathrm{~g}$ - $5.79 \mathrm{~g}$, Bozkurt (2017) reported shelled fruit weights of the almond genotypes selected from Datça peninsula as between $2.00 \mathrm{~g}-7.97 \mathrm{~g}$.

Present shelled fruit weights were not smaller than both the local types and cultivars and foreign cultivars. Kaşka et al. (1998) assessed the performance of Cristomorto, D. Largueta, Drake, Ferraduel, Ferragnes, Genco, Marcona, Nonpariel, Texas, Gülcan I, 101-9 and 101-13 cultivars under Southeastern Anatolia conditions and reported average shelled fruit weights as between $2.00 \mathrm{~g}-5.51 \mathrm{~g}$. Atlı et al. (2005) reported shelled fruit weights of 101/23, 17-4, 48-5, 48-2, 300-1, 48-1, 101-13, Nonpareil, Ferragnes, Cristomorto, Picantili, D. Largueta, Garrigues, Drake, Tuono, Primorski, Nikitski, Texas, Yaltinski and Ferraduel almond cultivars under Gaziantep 
conditions as between $1.26 \mathrm{~g}-3.91 \mathrm{~g}$; Akçay and Tosun (2005) reported shelled fruit weights of Ferrstar, Nonpareil, Cristomorto, Tuono, Ferragnes, Picantili, Yaltinski and Garrigues cultivars as between $2.65 \mathrm{~g}-4.80 \mathrm{~g}$.

Shelled fruit weights of promising almond genotypes were not also lower than both the shelled fruit weights of the genotypes obtained after selection breeding and the shelled fruit weights of the standard almond cultivars.

Shell thickness of promising genotypes varied between $0.93 \mathrm{~mm}$ (HTY-28) and $3.65 \mathrm{~mm}$ (HTY-65). Among the selected genotypes, while only 1 genotype had a shell structure classified as soft, 16 genotypes had hard shell and 2 genotypes had very hard shellstructure. According to Gülcan (1976), suture opening as an undesired attribute against the pests and diseases. Present study suture opening was not observed in promising almond genotypes (Table 2). In this sense, selected genotypes were found to be significant.

Table 2. Shelled fruit characteristics of selected genotypes.

Çizelge 2. Seçilen genotiplerin kabuklu meyve özellikleri.

\begin{tabular}{|c|c|c|c|c|c|c|c|}
\hline Genotype & $\begin{array}{l}\text { Shelled fruit } \\
\text { weight } \\
\text { (g) }\end{array}$ & $\begin{array}{c}\text { Shell } \\
\text { thickness } \\
(\mathbf{m m})\end{array}$ & $\begin{array}{c}\text { Shelled fruit } \\
\text { width } \\
\text { (mm) }\end{array}$ & $\begin{array}{c}\text { Shelled fruit } \\
\text { length } \\
(\mathbf{m m})\end{array}$ & $\begin{array}{c}\text { Shelled fruit } \\
\text { height } \\
(\mathbf{m m})\end{array}$ & $\begin{array}{l}\text { Suture } \\
\text { opening }\end{array}$ & $\begin{array}{c}\text { Shell } \\
\text { hardness }\end{array}$ \\
\hline HTY-11 & $3.68 \pm 0.30$ & $2.65 \pm 0.08$ & $20.19 \pm 1.17$ & $32.43 \pm 0.66$ & $16.52 \pm 0.83$ & No & Hard \\
\hline HTY-13 & $4.75 \pm 0.12$ & $3.31 \pm 0.01$ & $20.94 \pm 0.90$ & $35.74 \pm 0.93$ & $16.41 \pm 0.05$ & No & Hard \\
\hline HTY-14 & $4.04 \pm 0.25$ & $3.20 \pm 0.07$ & $19.79 \pm 0.40$ & $31.39 \pm 0.88$ & $16.11 \pm 0.59$ & No & Hard \\
\hline HTY-17 & $4.37 \pm 0.27$ & $3.33 \pm 0.06$ & $19.36 \pm 0.51$ & $35.27 \pm 0.56$ & $14.25 \pm 0.65$ & No & Hard \\
\hline HTY-25 & $2.99 \pm 0.10$ & $3.00 \pm 0.06$ & $20.16 \pm 0.32$ & $28.64 \pm 0.25$ & $14.79 \pm 0.07$ & No & Hard \\
\hline HTY-27 & $4.14 \pm 0.16$ & $2.77 \pm 0.10$ & $21.33 \pm 0.49$ & $34.56 \pm 0.75$ & $15.16 \pm 0.27$ & No & Hard \\
\hline HTY-28 & $1.55 \pm 0.06$ & $0.93 \pm 0.01$ & $15.43 \pm 0.02$ & $28.71 \pm 0.41$ & $12.81 \pm 0.33$ & No & Soft \\
\hline HTY-29 & $3.21 \pm 0.20$ & $2.55 \pm 0.04$ & $19.75 \pm 0.27$ & $28.42 \pm 0.42$ & $14.15 \pm 0.11$ & No & Hard \\
\hline HTY-31 & $3.97 \pm 0.40$ & $3.35 \pm 0.12$ & $23.17 \pm 0.94$ & $28.78 \pm 0.46$ & $17.17 \pm 0.68$ & No & Hard \\
\hline HTY-34 & $3.09 \pm 0.21$ & $2.96 \pm 0.16$ & $16.54 \pm 0.30$ & $33.69 \pm 0.46$ & $14.39 \pm 0.43$ & No & Hard \\
\hline HTY-40 & $4.01 \pm 0.16$ & $2.82 \pm 0.11$ & $20.42 \pm 0.40$ & $29.56 \pm 0.31$ & $16.23 \pm 0.21$ & No & Hard \\
\hline HTY-57 & $3.65 \pm 0.12$ & $2.63 \pm 0.10$ & $18.76 \pm 0.28$ & $31.28 \pm 1.34$ & $14.18 \pm 0.23$ & No & Very hard \\
\hline HTY-60 & $4.52 \pm 0.10$ & $2.51 \pm 0.10$ & $23.51 \pm 0.27$ & $32.78 \pm 1.05$ & $16.74 \pm 0.51$ & No & Hard \\
\hline HTY-62 & $4.31 \pm 0.30$ & $3.58 \pm 0.16$ & $24.44 \pm 0.66$ & $29.65 \pm 0.59$ & $16.61 \pm 0.59$ & No & Hard \\
\hline HTY-64 & $3.53 \pm 0.17$ & $2.91 \pm 0.14$ & $19.23 \pm 0.41$ & $32.09 \pm 0.44$ & $14.63 \pm 0.26$ & No & Hard \\
\hline HTY-65 & $5.73 \pm 0.29$ & $3.65 \pm 0.15$ & $25.84 \pm 0.88$ & $35.37 \pm 0.25$ & $17.94 \pm 0.54$ & No & Hard \\
\hline HTY-66 & $4.96 \pm 0.38$ & $2.46 \pm 0.18$ & $24.15 \pm 0.74$ & $33.55 \pm 0.42$ & $17.02 \pm 0.45$ & No & Very hard \\
\hline HTY-67 & $6.34 \pm 0.59$ & $3.41 \pm 0.03$ & $27.12 \pm 1.51$ & $33.97 \pm 1.66$ & $19.35 \pm 0.87$ & No & Hard \\
\hline HTY-68 & $5.67 \pm 0.33$ & $3.62 \pm 0.11$ & $25.78 \pm 0.83$ & $39.92 \pm 0.39$ & $18.17 \pm 0.59$ & No & Hard \\
\hline Minimum & 1.55 & 0.93 & 15.43 & 28.42 & 12.81 & & \\
\hline Maximum & 6.34 & 3.65 & 27.12 & 39.92 & 19.35 & & \\
\hline Mean & 4.13 & 2.93 & 21.36 & 32.41 & 15.93 & & \\
\hline
\end{tabular}

* HTY: Hatay.

Kernel weights of selected genotypes varied between $0.61 \mathrm{~g}$ (HTY-25) and $1.29 \mathrm{~g}$ (HTY-67) with an average value of $0.93 \mathrm{~g}$ (Table 3). Kernel weights of thegenotypes were significantly different. Kernel weights of 7 genotypes were greater than $1.00 \mathrm{~g}$ present findings on kernel weights were generally similar with the results reported by earlier researches carried out in Turkey. Kalyoncu (1990) reported kernel weights of the almonds around the reservoir of Konya Apa Dam as between $0.64 \mathrm{~g}-1.00 \mathrm{~g}$, Aslantaş (1993) reported kernel weights of the almond genotypes selected from Erzincan Kemaliye town as between $0.65 \mathrm{~g}-1.15 \mathrm{~g}$, Beyhan and Bostan (1995) reported kernel weights of almonds in Darende locality as between $0.77 \mathrm{~g}-1.23 \mathrm{~g}$, Karadeniz and Erman (1996) reported kernel weights of the almond genotypes selected from Siirt province as between $1.01 \mathrm{~g}-1.80 \mathrm{~g}$, Yıldırım (2007) reported kernel weights of promising almond genotypes selected from Isparta province as between $0.99 \mathrm{~g}$ - $1.27 \mathrm{~g}$, Göksu (2011) reported kernel weights of the almond genotypes selected from Adıyaman province as between $0.60 \mathrm{~g}-1.04 \mathrm{~g}$.

Present findings on kernel weights were parallel to the kernel weights obtained from earlier selection studies carried out in Turkey, but the present values were lower than the values of standard almond cultivars. Kaşka et al. (1998) carried out a study at Şanlıurfa Koruklu Research Station in 1996 with the local genotypes of 48-1, 482 and 48-5 and foreign cultivars of Drake, Nonpareil and Texas and reported kernel weights respectively as 1.56 $\mathrm{g}, 1.74 \mathrm{~g}, 1.34 \mathrm{~g}, 1.46 \mathrm{~g}$ and $1.73 \mathrm{~g}$. Vargas (1998) carried out a study at IRTA (Spain) on fruit characteristics of 20 almond cultivars and reported kernel weights as between $1.0 \mathrm{~g}-2.3 \mathrm{~g}$. Akçay and Tosun (2005) worked with 
foreign almond cultivars of Ferrastar, Nonpareil, Cristomorto, Tuono, Ferragnes, Picantili, Yaltinski and Garrigues and reported kernel weights as between $1.35 \mathrm{~g}-2.00 \mathrm{~g}$.

Kernel weights were determined through weighing and number of kernels placed into 1 onz $(28.3 \mathrm{~g})$ is provided in Table 3. The number of kernels placed in $1 \mathrm{onz}$ standard size varied between 46.39 (HTY-25) and 21.99 (HTY-67) with an average value of 31.82. Of the present promising genotypes, kernels were classified as small in 11 genotypes, medium in 5 genotypes, large in 3 genotypes and there were not any very large kernels. It is remarkable that present number of kernels placed in 1 onz was little bit low. Gülcan (1976) investigated 200 almond genotypes and reported number of kernels in 1 onz as between 14- 49, Balta (2002) reported the number of kernels in $1 \mathrm{onz}$ as between 21 - 35, Yıldırım (2007) reported the value of promising genotypesas between 22 - 32, Yeşilkaynak (2000) worked with standard almond cultivars of Drake, Yaltınski, Cristomorto, Ferragnes, Tuono, Garrigues 112, Nonpariel and 48-5 and reported the number of kernels in 1 onz respectively as $14,14,15,16,19,20,22$ and 26.

Present kernel weights and the number of kernels in $1 \mathrm{onz}$ were lower than the values of standard almond cultivars since cultural practices were not implemented on selected genotypes and they were naturally growing over dry and stony lands.

Table 3. Kernel characteristics of selected genotypes.

Çizelge 3. Seçilen genotiplerin iç meyve özellikleri.

\begin{tabular}{|c|c|c|c|c|c|c|}
\hline Genotype & $\begin{array}{c}\text { Kernel } \\
\text { weight } \\
\text { (g) }\end{array}$ & $\begin{array}{l}\text { Kernel } \\
\text { width } \\
\text { (mm) }\end{array}$ & $\begin{array}{l}\text { Kernel } \\
\text { length } \\
(\mathbf{m m})\end{array}$ & $\begin{array}{l}\text { Kernel height } \\
(\mathbf{m m})\end{array}$ & $\begin{array}{c}\text { Number of } \\
\text { kernels in } 1 \\
\text { onz }\end{array}$ & $\begin{array}{c}\text { Fruit bulkiness } \\
\text { based on number of } \\
\text { kernels in } 1 \text { onz }\end{array}$ \\
\hline HTY-11 & $0.92 \pm 0.04$ & $10.37 \pm 0.25$ & $23.37 \pm 0.17$ & $8.03 \pm 0.69$ & $30.87 \pm 0.04$ & Small \\
\hline HTY-13 & $1.01 \pm 0.02$ & $11.54 \pm 0.03$ & $25.66 \pm 0.66$ & $6.75 \pm 0.08$ & $28.02 \pm 0.02$ & Medium \\
\hline HTY-14 & $0.81 \pm 0.04$ & $11.57 \pm 0.60$ & $21.04 \pm 0.54$ & $7.04 \pm 0.08$ & $34.80 \pm 0.04$ & Small \\
\hline HTY-17 & $0.70 \pm 0.01$ & $11.00 \pm 0.16$ & $23.07 \pm 0.05$ & $5.36 \pm 0.06$ & $40.62 \pm 0.01$ & Small \\
\hline HTY-25 & $0.61 \pm 0.02$ & $11.62 \pm 0.37$ & $19.79 \pm 0.35$ & $5.47 \pm 0.10$ & $46.39 \pm 0.02$ & Small \\
\hline HTY-27 & $0.97 \pm 0.01$ & $12.18 \pm 0.48$ & $24.35 \pm 0.64$ & $6.45 \pm 0.48$ & $29.08 \pm 0.01$ & Medium \\
\hline HTY-28 & $0.78 \pm 0.01$ & $10.02 \pm 0.06$ & $20.81 \pm 1.60$ & $7.23 \pm 0.18$ & $36.28 \pm 0.01$ & Small \\
\hline HTY-29 & $0.69 \pm 0.04$ & $10.51 \pm 0.56$ & $20.11 \pm 0.55$ & $6.62 \pm 0.08$ & $41.21 \pm 0.04$ & Small \\
\hline HTY-31 & $0.86 \pm 0.02$ & $12.00 \pm 0.39$ & $20.32 \pm 0.15$ & $6.85 \pm 0.40$ & $33.04 \pm 0.02$ & Small \\
\hline HTY-34 & $0.77 \pm 0.04$ & $11.76 \pm 0.79$ & $20.99 \pm 1.47$ & $6.37 \pm 0.80$ & $36.59 \pm 0.04$ & Small \\
\hline HTY-40 & $0.81 \pm 0.03$ & $11.58 \pm 0.17$ & $21.03 \pm 0.03$ & $7.11 \pm 0.09$ & $34.80 \pm 0.03$ & Small \\
\hline HTY-57 & $0.89 \pm 0.04$ & $12.23 \pm 0.28$ & $20.77 \pm 0.45$ & $7.42 \pm 0.20$ & $31.68 \pm 0.04$ & Small \\
\hline HTY-60 & $1.07 \pm 0.05$ & $14.36 \pm 0.77$ & $24.50 \pm 0.52$ & $6.26 \pm 0.18$ & $26.37 \pm 0.05$ & Medium \\
\hline HTY-62 & $1.24 \pm 0.02$ & $14.27 \pm 0.65$ & $22.17 \pm 0.85$ & $8.07 \pm 0.37$ & $22.88 \pm 0.02$ & Large \\
\hline HTY-64 & $0.85 \pm 0.06$ & $11.53 \pm 0.45$ & $21.97 \pm 0.71$ & $6.69 \pm 0.50$ & $33.29 \pm 0.06$ & Small \\
\hline HTY-65 & $1.11 \pm 0.05$ & $13.98 \pm 0.42$ & $22.80 \pm 0.74$ & $7.25 \pm 0.24$ & $25.50 \pm 0.05$ & Medium \\
\hline HTY-66 & $1.04 \pm 0.06$ & $13.65 \pm 0.19$ & $22.54 \pm 0.59$ & $7.09 \pm 0.17$ & $27.12 \pm 0.06$ & Medium \\
\hline HTY-67 & $1.29 \pm 0.03$ & $15.84 \pm 0.44$ & $24.16 \pm 1.21$ & $6.37 \pm 0.05$ & $21.99 \pm 0.03$ & Large \\
\hline HTY-68 & $1.18 \pm 0.02$ & $14.02 \pm 0.55$ & $25.23 \pm 0.31$ & $6.90 \pm 0.16$ & $23.98 \pm 0.02$ & Large \\
\hline Minimum & 0.61 & 10.02 & 19.79 & 5.36 & 21.99 & \\
\hline Maximum & 1.29 & 15.84 & 25.66 & 8.07 & 46.39 & \\
\hline Mean & 0.93 & 12.32 & 22.35 & 6.81 & 31.82 & \\
\hline
\end{tabular}

* HTY: Hatay.

Since kernels constitute the primary edible part of almonds, selection studies mostly focus on kernel ratio which is expressed as the ratio of shelled fruit weight to kernel weight. Usually high kernel ratios are desired in almonds (Yıldırım, 2007). Present kernel ratios varied between 15.99\% (HTY-17) and 50.46\% (HTY-28) (Table 4). These values were similar with the findings of earlier selection studies carried out in Turkey. For instance, Cangi and Şen (1991) reported kernel ratio of the genotypes selected from Vezirköprü locality as between 18.20 $30.00 \%$, Balta (2002) carried out a study in Elazığ central and Ağın district and reported kernel ratios as between $12.98-48.01 \%$, Göksu (2011) in a selection study carried out in Adıyaman province, reported kernel ratios as between $46.67-52.32 \%$, Köse (2013) reported the kernel ratios of almond genotypes selected from İspir town as between $17.36-26.11 \%$, Bozkurt (2017) reported the kernel ratios of the genotypes selected from Datça peninsula as between $21.76-66.50 \%$.

Kaşka et al. (1998) reported kernel ratios of some local and foreign almond cultivars as between $23.33 \%$ (Ferraduel) and 39.50\% (Yaltinski); Atlı et al. (2005) reported kernel ratios of 20 local and thirteen foreign almond cultivars as between $25.90 \%$ (D. Largueta) and 59.10\% (17-4). Akçay and Tosun (2005) reported kernel 
ratios of Ferrastar, Nonpareil, Cristomorto, Tuono, Ferragnes, Picantili, Yaltinski and Garrigues almond cultivars respectively as $33.30,51.03,33.85,35.13,38.41,52.00,47.58$ and $33.85 \%$.

Except for HTY-28 genotype, kernel ratios of present almond genotypes were lower than the kernel ratios of standard cultivars. However, present values were still within the normal limits. Generally there is an inverse relationship between shelled fruit weight and kernel ratio and hard-shell almonds have low, but soft-shell ones have high kernel ratios (Gülcan, 1976; Özbek, 1978). Endocarp thickness is greater in hard-shell almonds than in soft-shell ones. In this study, all of the selected promising genotypes had very hard shell structure. Relatively greater kernel ratios are expected from well-cared orchards.

Double kernel ratios of the selected genotypes varied between $0.00-16.67 \%$ with an average value of $8 \%$ andempty fruit ratios varied between $0.00-13.33 \%$ with an average value of $2.14 \%$ (Table 4). Double kernel ratio is largely a cultivar-specific characteristic, but low temperatures at flowering period may increase double kernel ratios (Asensio et al., 1996; Balta, 2002). Double kernel is not desired commercially, thus the genotypes with low ratios are preferred in practice. In this sense, present genotypes were considered as commercially valuable.

Recent researches have revealed significant effects of almonds on cholesterol levels and cardiovascular diseases. Especially the oil content, fatty acids and protein content play significant roles in human health. Total oil contents of the selected genotypes varied between $44.65 \%$ (HTY-40) and 54.56\% (HTY-14) and protein contents varied between 19.59\% (HTY-27) and 33.79\% (HTY-57) (Table 4).

Present oil and protein contents of the genotypes were similar with the findings of earlier studies carried out in Turkey. Balta et al. (2001) reported total oil contents of the genotypes selected from Van province as between 48.70-69.90\% and protein contents as between 22.20-24.30\%, Yıldırım (2007) reported the total oil contents of the genotypes selected from Isparta province as between $44.25-54.68 \%$ and protein contents as between 21.23 $35.27 \%$, Şimşek and Demirkıran (2010) reported total oil contents of the genotypes selected from Diyarbakır province as between 43.50-54.81\% and protein contents as between 21.18- 32.90\%, Gülsoy and Balta (2014) reported total oil contents of the genotypes selected from Yenipazar, Bozdoğan and Karacasu towns of Aydın province as between $48.10-63.10 \%$ and protein contents as between $25.70-32.90 \%$.

Similar findings were also reported for standard almond cultivars. For instance, Gradziel et el. (2001) worked with almond cultivars of Mission, Ne plus Ultra, Nonpareil, Sonora, Peerless, Carmel and Butte and reported total oil contents respectively as 49.6, 47.6, 43.6, 42.2, 41.6, 44.9 and 50.2\%. Ahrens et al. (2005) indicated that almond was quite rich in protein, oil, minerals, fiber and vitamin $\mathrm{E}$ and reported oil contents of Texas, Nonpareil and Carmel almond cultivars as between $43.37-47.50 \%$ and protein contents as between $20.68-23.30 \%$.

Oil and protein contents of almond genotypes are influenced by cultural practices.Besides, tree age and yield status also influence these attributes. Selected almond genotypes should be grown under the same conditions with the standard cultivars and then compared with them.

Light kernel colors are desired in commercial almond culture. On the other hand, hard shell color is not that much significant, but raise allure of the fruits and largely preferred in exports and imports. With regard to shelled fruit color, 8 genotypes were classified as light, 7 as medium and 4 as dark (Table 5). With regard to kernel color, 6 genotypes were classified as light, 9 as medium and 4 as dark (Table 6). Both shelled fruit and kernel color are significant quality parameters in almonds. Color can change with ripening duration, drying temperature and duration. It is also a hereditary attribute than can change from one genotype to another (Aslantaş, 1993; Ağlar and Balta, 2007). Present promising almond genotypes were mostly classified as medium with regard to both shelled fruit and kernel color. Since Hatay province has sub-tropical climate conditions with quite high temperatures at ripening periods. Thus, fruit colors might have been influenced by those hot temperatures. The subjective observations well complied with color-meter measurements. 
Table 4. Kernel ratio and chemical attributes of selected genotypes.

Çizelge 4. Seçilen genotplerin iç meyve oranı ve biyokimyasal özellikleri.

\begin{tabular}{lccccc}
\hline Genotype & $\begin{array}{c}\text { Kernel ratio } \\
\text { (\%) }\end{array}$ & $\begin{array}{c}\text { Double kernel ratio } \\
(\%)\end{array}$ & $\begin{array}{c}\text { Empty fruit ratio } \\
\text { (\%) }\end{array}$ & $\begin{array}{c}\text { Total oil content } \\
\text { (\%) }\end{array}$ & $\begin{array}{c}\text { Protein content } \\
\text { (\%) }\end{array}$ \\
\hline HTY-11 & 25.05 & 16.67 & 0.00 & 52.84 & 24.40 \\
HTY-13 & 21.27 & 0.00 & 0.00 & 45.31 & 22.57 \\
HTY-14 & 20.17 & 13.33 & 0.00 & 54.56 & 23.97 \\
HTY-17 & 15.99 & 6.67 & 0.00 & 51.85 & 24.73 \\
HTY-25 & 20.44 & 0.00 & 13.33 & 48.42 & 21.84 \\
HTY-27 & 23.51 & 0.00 & 3.33 & 45.20 & 19.59 \\
HTY-28 & 50.46 & 3.33 & 6.67 & 51.10 & 24.95 \\
HTY-29 & 21.43 & 16.67 & 3.33 & 49.27 & 24.78 \\
HTY-31 & 21.76 & 16.67 & 0.00 & 50.61 & 20.51 \\
HTY-34 & 25.04 & 0.00 & 0.00 & 46.81 & 25.08 \\
HTY-40 & 20.31 & 13.33 & 3.33 & 44.65 & 28.76 \\
HTY-57 & 24.52 & 3.33 & 0.00 & 51.17 & 33.79 \\
HTY-60 & 23.72 & 0.00 & 0.00 & 53.41 & 28.63 \\
HTY-62 & 28.80 & 12.00 & 4.00 & 46.75 & 23.44 \\
HTY-64 & 24.14 & 0.00 & 0.00 & 50.03 & 24.71 \\
HTY-65 & 19.42 & 6.67 & 3.33 & 54.25 & 22.83 \\
HTY-66 & 21.07 & 10.00 & 0.00 & 51.18 & 21.73 \\
HTY-67 & 20.44 & 16.67 & 0.00 & 49.06 & 23.73 \\
HTY-68 & 20.84 & 16.67 & 3.33 & 45.27 & 27.80 \\
\hline Minimum & 15.99 & 0.00 & 0.00 & 44.65 & 19.59 \\
Maximum & 50.46 & 16.67 & 2.14 & 54.56 & 33.79 \\
Mean & 23.60 & 8.00 & & 49.57 & 24.62 \\
\hline$* H T: H a y$ & & &
\end{tabular}

* HTY: Hatay.

Table 5. Shelled fruit color characteristics of the selected genotypes.

Çizelge 5. Seçilen genotiplerin kabuklu meyve renk özellikleri.

\begin{tabular}{|c|c|c|c|c|c|c|}
\hline \multirow[t]{2}{*}{ Genotype } & \multicolumn{6}{|c|}{ Shelled fruit color } \\
\hline & $\begin{array}{c}\text { Subjective } \\
\text { Observation }\end{array}$ & $\mathbf{L}$ & $a^{*}$ & $\mathbf{b}^{*}$ & C & $h^{\circ}$ \\
\hline HTY-11 & Light & $67.99 \pm 1.08$ & $8.52 \pm 0.23$ & $24.74 \pm 0.60$ & $26.18 \pm 057$ & $70.96 \pm 0.67$ \\
\hline HTY-13 & Medium & $60.86 \pm 0.39$ & $9.02 \pm 0.07$ & $28.34 \pm 0.21$ & $29.75 \pm 0.22$ & $72.34 \pm 0.03$ \\
\hline HTY-14 & Dark & $58.49 \pm 0.65$ & $9.85 \pm 0.18$ & $29.78 \pm 0.53$ & $31.37 \pm 0.54$ & $71.69 \pm 0.25$ \\
\hline HTY-17 & Medium & $62.39 \pm 0.75$ & $7.74 \pm 0.07$ & $24.32 \pm 0.24$ & $25.53 \pm 0.23$ & $72.34 \pm 0.24$ \\
\hline HTY-25 & Light & $64.79 \pm 0.34$ & $9.70 \pm 0.10$ & $29.31 \pm 0.09$ & $30.87 \pm 0.11$ & $71.65 \pm 0.15$ \\
\hline HTY-27 & Light & $63.99 \pm 0.53$ & $7.98 \pm 0.17$ & $27.29 \pm 0.24$ & $28.45 \pm 0.26$ & $73.65 \pm 0.23$ \\
\hline HTY-28 & Light & $66.89 \pm 1.02$ & $9.38 \pm 0.13$ & $32.36 \pm 0.31$ & $33.71 \pm 0.26$ & $73.80 \pm 0.37$ \\
\hline HTY-29 & Light & $64.10 \pm 0.85$ & $8.46 \pm 0.09$ & $25.71 \pm 0.26$ & $27.08 \pm 0.25$ & $71.77 \pm 0.23$ \\
\hline HTY-31 & Medium & $63.95 \pm 0.47$ & $8.58 \pm 0.97$ & $27.91 \pm 1.18$ & $29.22 \pm 1.42$ & $72.90 \pm 1.10$ \\
\hline HTY-34 & Light & $61.62 \pm 0.71$ & $9.57 \pm 0.05$ & $26.44 \pm 0.51$ & $28.13 \pm 0.47$ & $70.01 \pm 0.43$ \\
\hline HTY-40 & Medium & $61.66 \pm 0.39$ & $8.60 \pm 0.07$ & $27.51 \pm 0.42$ & $28.84 \pm 0.38$ & $72.60 \pm 0.41$ \\
\hline HTY-57 & Light & $63.04 \pm 0.80$ & $9.83 \pm 0.27$ & $26.64 \pm 0.44$ & $28.40 \pm 0.50$ & $69.74 \pm 0.21$ \\
\hline HTY-60 & Dark & $56.33 \pm 0.80$ & $10.79 \pm 0.17$ & $29.28 \pm 0.19$ & $31.22 \pm 0.12$ & $69.73 \pm 0.42$ \\
\hline HTY-62 & Medium & $65.01 \pm 1.11$ & $9.02 \pm 0.23$ & $26.65 \pm 0.51$ & $28.14 \pm 0.48$ & $71.26 \pm 0.59$ \\
\hline HTY-64 & Dark & $56.01 \pm 1.39$ & $10.71 \pm 0.26$ & $29.92 \pm 0.80$ & $31.79 \pm 0.84$ & $69.12 \pm 2.05$ \\
\hline HTY-65 & Light & $61.78 \pm 0.58$ & $9.10 \pm 0.04$ & $23.85 \pm 0.45$ & $25.53 \pm 0.41$ & $69.07 \pm 0.39$ \\
\hline HTY-66 & Medium & $62.69 \pm 1.23$ & $8.75 \pm 0.15$ & $22.79 \pm 0.59$ & $24.42 \pm 0.60$ & $68.98 \pm 0.29$ \\
\hline HTY-67 & Medium & $56.85 \pm 0.26$ & $9.44 \pm 0.07$ & $25.93 \pm 0.34$ & $27.60 \pm 0.31$ & $69.96 \pm 0.30$ \\
\hline HTY-68 & Dark & $58.47 \pm 0.16$ & $9.76 \pm 0.14$ & $27.33 \pm 0.21$ & $29.03 \pm 0.23$ & $70.29 \pm 0.21$ \\
\hline Minimum & & 56.01 & 7.74 & 22.79 & 24.42 & 68.98 \\
\hline Maximum & & 67.99 & 10.79 & 32.36 & 33.71 & 73.80 \\
\hline Mean & & 61.95 & 9.20 & 27.16 & 28.70 & 71.15 \\
\hline
\end{tabular}

* HTY: Hatay. 
Table 6. Kernel color characteristics of the selected genotypes.

Çizelge 6. Seçilen genotiplerin iç meyve renk özellikleri.

\begin{tabular}{|c|c|c|c|c|c|c|}
\hline \multirow[t]{2}{*}{ Genotype } & \multicolumn{6}{|c|}{ Kernel color } \\
\hline & $\begin{array}{l}\text { Subjective } \\
\text { observation }\end{array}$ & $\mathbf{L}$ & $a^{*}$ & $\mathbf{b}^{*}$ & $C$ & $h^{\circ}$ \\
\hline HTY-11 & Medium & $44.61 \pm 0.46$ & $14.88 \pm 0.21$ & $30.96 \pm 2.66$ & $34.45 \pm 2.50$ & $63.64 \pm 1.04$ \\
\hline HTY-13 & Medium & $45.03 \pm 0.21$ & $16.15 \pm 0.75$ & $33.63 \pm 0.70$ & $37.56 \pm 0.48$ & $63.88 \pm 1.09$ \\
\hline HTY-14 & Light & $52.87 \pm 0.52$ & $13.33 \pm 0.29$ & $35.56 \pm 0.63$ & $37.98 \pm 0.66$ & $69.44 \pm 0.34$ \\
\hline HTY-17 & Light & $49.06 \pm 0.62$ & $15.87 \pm 0.09$ & $36.35 \pm 0.62$ & $39.67 \pm 0.53$ & $66.39 \pm 0.93$ \\
\hline HTY-25 & Light & $49.09 \pm 0.82$ & $16.16 \pm 0.17$ & $34.70 \pm 1.08$ & $38.31 \pm 0.95$ & $64.82 \pm 1.06$ \\
\hline HTY-27 & Light & $52.01 \pm 0.48$ & $14.19 \pm 0.15$ & $36.93 \pm 3.60$ & $39.69 \pm 3.40$ & $68.07 \pm 0.80$ \\
\hline HTY-28 & Light & $42.16 \pm 0.28$ & $18.38 \pm 0.55$ & $33.86 \pm 0.85$ & $38.53 \pm 0.86$ & $61.48 \pm 1.11$ \\
\hline HTY-29 & Medium & $46.31 \pm 0.95$ & $12.81 \pm 0.68$ & $31.76 \pm 1.56$ & $34.29 \pm 1.45$ & $67.83 \pm 0.51$ \\
\hline HTY-31 & Medium & $41.94 \pm 0.40$ & $16.44 \pm 0.14$ & $31.41 \pm 1.20$ & $35.47 \pm 1.03$ & $62.22 \pm 0.29$ \\
\hline HTY-34 & Medium & $38.71 \pm 0.39$ & $16.07 \pm 0.46$ & $27.86 \pm 4.48$ & $32.32 \pm 4.09$ & $59.04 \pm 4.98$ \\
\hline HTY-40 & Medium & $40.19 \pm 0.85$ & $16.17 \pm 0.62$ & $26.82 \pm 0.73$ & $31.38 \pm 0.34$ & $58.82 \pm 0.75$ \\
\hline HTY-57 & Medium & $44.16 \pm 0.53$ & $16.50 \pm 0.40$ & $30.44 \pm 0.86$ & $34.63 \pm 0.93$ & $61.51 \pm 0.82$ \\
\hline HTY-60 & Dark & $41.45 \pm 1.04$ & $14.45 \pm 0.35$ & $28.44 \pm 2.13$ & $32.14 \pm 1.81$ & $61.26 \pm 1.19$ \\
\hline HTY-62 & Dark & $49.18 \pm 0.71$ & $16.01 \pm 0.22$ & $33.01 \pm 2.74$ & $36.79 \pm 2.66$ & $63.47 \pm 0.66$ \\
\hline HTY-64 & Light & $41.74 \pm 0.34$ & $17.17 \pm 0.67$ & $32.32 \pm 0.57$ & $36.61 \pm 0.72$ & $61.97 \pm 0.20$ \\
\hline HTY-65 & Medium & $46.18 \pm 1.28$ & $16.01 \pm 0.16$ & $33.30 \pm 0.06$ & $36.96 \pm 0.13$ & $64.28 \pm 0.64$ \\
\hline HTY-66 & Dark & $45.90 \pm 0.32$ & $15.97 \pm 0.18$ & $35.65 \pm 1.11$ & $39.12 \pm 0.98$ & $65.57 \pm 0.70$ \\
\hline HTY-67 & Medium & $50.11 \pm 1.01$ & $15.58 \pm 0.34$ & $31.58 \pm 1.39$ & $35.23 \pm 1.37$ & $63.64 \pm 0.83$ \\
\hline HTY-68 & Dark & $42.09 \pm 2.24$ & $19.38 \pm 7.51$ & $30.16 \pm 6.93$ & $41.99 \pm 7.92$ & $65.12 \pm 0.50$ \\
\hline Minimum & & 38.71 & 12.81 & 26.82 & 31.38 & 58.82 \\
\hline Maximum & & 52.87 & 19.38 & 36.93 & 41.99 & 69.44 \\
\hline Mean & & 45.41 & 15.87 & 32.35 & 36.48 & 63.81 \\
\hline
\end{tabular}

* HTY: Hatay.

\section{CONCLUSION}

This study was conducted with almond genotypes selected from natural populations of Hatay province and present findings revealed that selected genotypes had a broad variation in fruit characteristics. Selected promising genotypes (19 genotypes) did not have smaller values for fruit quality attributes than both the standard cultivars and the genotypes selected in earlier breeding studies. A comparative adaptation study is recommended to be carried out with the present genotypes, standard cultivars and the genotypes selected from different regions. Such a study may have great contributions to both regional and national almond culture.

\section{ACKNOWLEDGMENT}

This study is a part of first author' Master Science theses, and it was supported by Scientific Research Projects Department of Hatay Mustafa Kemal University (with the project number of 1104 Y 0101).

\section{REFERENCES}

Ağlar, E. (2005). Pertek (Tunceli) yöresi bademlerinin (Prunus amygdalus L.) seleksiyonu. Yüksek LisansTezi, Yüzüncü Yıl Üniversitesi, Fen Bilimleri Enstitüsü, Van.

Ağlar, E., \& Balta, F. (2007). Pertek (Tunceli) Yöresi Badem Seleksiyonu. V. Ulusal Bahçe Bitkileri Kongresi, Erzurum.

Ahrens, S., Venkatachalam, M., Mistry, A. M., Lapsley, K., \& Sahte, S. K. (2005). Almond (Prunus dulcis L.) protein quality. Plant Foods for Human Nutrition, 60, 123-128.

Akçay, M. E., \& Tosun, İ. (2005). Bazı geç çiçek açan yabancı badem çeşitlerinin Yalova ekolojik koşullarındaki gelişme ve verim davranışları. Atatürk Üniversitesi Ziraat Fakültesi Dergisi, 36(1), 1-5.

Akyüz, N., \& Kaya, G. (1992). Gıda Kimyası Laboratuarı. Yüzüncü Yıl Üniversitesi Fen-Edebiyat Fakültesi, Yayın No: 2, Van.

Asensio, M. C., Socras, I., \& Company, R. (1996). Double kernel in almond. An Open Question, Nucis, 5, 8-9.

Aslantaş, R. (1993). Erzincan ili Kemaliye ilçesinde doğal olarak yetişen bademlerin (Amygdalus communis l.) seleksiyon yoluyla ıslahı üzerinde bir araştırma. Yüksek Lisans Tezi, Atatürk Üniversitesi, Fen Bilimleri Enstitüsü, Erzurum. 
Atlı, H.S., Açar, I., Arpacı, S., Akgün, A., Aydın, Y., \& Bilim, C. (2005). Yerli ve yabancı değişik badem çeşitlerinin Gap bölgesi sulu koşullarında gelişme, meyveye yatma, verim ve bazı kalite değerlerinin karşılaştırılması. Gap IV. Tarım Kongresi, Şanlıurfa.

Balta, F., Yarılgaç, T., \& Balta, F. (2001). Fruit characterstics of native almond selections from the lake Van region (Eastern Anatolia, Turkey). Journal American Pomological Society, 55(1), 58-61.

Balta, M. F. (2002). Elazığ merkez ve Ağın ilçesi bademlerinin (Prunus amygdalus L.) seleksiyon yoluyla ıslahı üzerinde araştırmalar. (MSc), Yüzüncü Yıl Üniversitesi, Fen Bilimleri Enstitüsü, Van.

Beyhan, Ö., \& Bostan, S. Z. (1995). Darende bademlerinin seleksiyon yoluyla ıslahı üzerine bir araştırma. Yüzüncü Yıl Üniversitesi Ziraat Fakültesi Dergisi, 5(1), 91-100.

Bostan, S. Z., Cangi, R., \& Oğuz, H. İ. (1995). Akdamar adası bademlerinin (Prunus amygdalus L.) seleksiyon yoluyla ıslahı üzerine araştırmalar. Türkiye II. Ulusal Bahçe Bitkileri Kongresi, Adana.

Bozkurt, T. (2017). Datça (Muğla) ilçesinde doğal olarak yetişen bademlerin (Amygdalus communis l. ) seleksiyonu. Yüksek LisansTezi, Atatürk Üniversitesi, Fen Bilimleri Üniversitesi, Erzurum.

Cangi, R., \& Şen, S. M. (1991). Vezirköprü ve çevresinde yetiştirilen bademlerin seleksiyon yoluyla ıslahı üzerine araştırmalar. Yüzüncü Yıl Üniversitesi Ziraat Fakültesi Dergisi, 1, 131-152.

Dicenta, F., Egea, J., \& Berenguer, T. (1999). Five years of observations of the grempa almond collection in cebascsıc, (Murcia, Spain). XI. Grempa Meeting On Pistacios And Almonds, University of Harran, Faculty Of Agriculture-Pistacio Research And Application Center, Şanlıurfa, Turkey.

Dokuzoğuz, M., Gülcan, R., \& Atila, A. (1968). Ege Bölgesi Bademlerinin Seleksiyon Yoluyla Islahı Üzerinde Araştırmalar. Ege Üniversitesi Ziraat Fakültesi Yayınları No:148, İzmir.

Dokuzoğuz, M., \& Gülcan, R. (1973). Ege Bölgesi Bademlerinin Seleksiyon Yoluyla Islahı Ve Seçilmiş Tiplerin Adaptasyonu Üzerinde Araştırmalar. Tübitak, Toag Yayınları No:22, Ankara.

Gerçekcioğlu, R., \& Güneş, M. (1999). A Research on Improvement of Almond (Amygdalus communis L.) by Selection of Wild Plants Grown in Tokat Central District. XI. Grempa Meeting on Pistacios and Almonds, University of Harran, Faculty of Agriculture-Pistacio Research and Application Center, Şanlıurfa, Turkey.

Gradziel, T. M., Martinez-Gomez, P., Dicenta, F., \& Kester, D. E. (2001). The utilization of related prunus species for almond variety improvement. Journal American Pomological Society, 55(2), 100-108.

Gülcan, R. (1976). Seçilmiş Badem Tipleri Üzerinde Fizyolojik ve Morfolojik Araştırmalar. Ege Üniversitesi Ziraat Fakültesi Yayınları No: 310, Izmir.

Göksu, A. (2011). Adıyaman merkez ilçe bademlerinin (Prunus Amygdalus L.) seleksiyonu Yüksek LisansTezi, Gaziosmanpaşa Üniversitesi, Fen Bilimleri Enstitüsü, Tokat.

Gülsoy, E., \& Balta, F. (2014). Aydın ili Yenipazar, Bozdoğan ve Karacasu ilçelerinden selekte edilen badem (Prunus amygdalus Batch) genotiplerinin protein, yağ ve yağ asidi bileşimlerinin belirlenmesi. Iğdır Üniversitesi Fen Bilimleri Enstitüsü Dergisi, 4(1), 9-14.

Kaçar, B. (1984). Bitki Besleme ve Uygulama Kılavuzu. Ankara.

Kalyoncu, I.H. (1990). Konya Apa baraj gölü çevresinde yetiştirilen üstün özellikli badem (prunus amygdalusl.) tiplerinin belirlenmesi üzerine bir seleksiyon çalişmasi. Yüksek LisansTezi, Ondokuz Mayıs Üniversitesi, Fen Bilimleri Enstitüsü, Samsun.

Karadeniz, T., Balta, F., Cangi, R., \& Yarılgaç, T. (1996). Adır Adası (Vangölü) bademlerinin (Amygdalus communis L.) seleksiyon yoluyla ıslahı. I. Fındık ve Diğer Sert Kabuklu Meyveler Sempozyumu, Ondokuz Mayıs Üniversitesi, Samsun.

Karadeniz, T., \& Erman, P. (1996). Sürt'te yetiştirilen bademlerin (Amygdalus communis L.) seleksiyonu. I. Fındık ve Diğer Kabuklu Meyveler Sempozyumu, Ondokuz Mayıs Üniversitesi, Samsun.

Kaşka, N., Küden, A. B., \& Küden, A. (1998). Performances of some local and foreign almond cultivars in South East Anatolia. Advanced Course. Production And Economics of Nut Corps. Adana.

Köse, M. (2013). Erzurum ili İspir ilçesinde doğal olarak yetişen badem (amygdalus communis l.) tiplerinin seleksiyon yolu ile ıslahı ve seçilen tiplerde rapd yöntemiyle genetik çeşitliliğin belirlenmesi. Yüksek LisansTezi, Atatürk Üniversitesi, Fen Bilimleri Enstitüsü, Erzurum.

Noronha Vaz, M.T. (1996). Recent Portuguese development in the nut sector. Ciheam- Iamz. FAO, Zaragoza, Spain.

Özbek, S. (1978). Özel Meyvecilik. Çukurova Üniversitesi Ziraat Fakültesi Yayınları: 128, Adana.

Soylu, A. (2003). Ilıman iklim meyveleri. II. Uludağ Üniversitesi Ziraat Fakültesi Ders Notları, No:72, Bursa. 
Şimşek, M. (1996). Kahramanmaraş merkez ilçesi ve bağlı köylerinde badem (Amygdalus communis L.) seleksiyon yoluyla ıslahı üzerine bir araştırma. Yüksek LisansTezi, Kahramanmaraş Sütçü İmam Üniversitesi, Fen Bilimleri Enstitüsü, Kahramanmaraş.

Şimşek, M., \& Demirkıran, A. (2010). Determination of superior almond genotypes in Diyarbakır central districts. Agricultral Journal, 5(3), 173-180.

Tosun, İ. (2002). Badem Yetiştiriciliği. Atatürk Bahçe Kültürleri Merkez Araştırma Enstitüsü Yalova.

UPOV 2011. International Union For The Protection of New Varieties of Plants. TG/56/4, Almond.

Vargas, F. J. (1998). Almond: Choice and Breeding of Varieties. Advanced Course Production and Economics of Nut Crops, Adana (Turkey).

Yeşilkaynak, B. (2000). Değişik kökenli badem çeşitlerinin Kahramanmaraş ekolojik koşullarında büyüme, gelişme ve meyve verme durumlarının saptanması üzerine bir araştırma. Yüksek LisansTezi, Kahramanmaraş Sütçü İmam Üniversitesi, Fen Bilimleri Enstitüsü, Kahramanmaraş.

Yıldırım, A. (2007). Isparta yöresi bademlerinin (Prunus amygdalus L.) seleksiyonu. Yüksek LisansTezi, Adnan Menderes Üniversitesi, Fen Bilimleri Enstitüsü, Isparta.

Yıldırım, A. N., Tekintaş, E., \& Koyuncu, F. (2007). Isparta bölgesinde geç çiçeklenen ve üstün nitelikli meyve veren badem (Prunus Amygdalus Batsch.) genotiplerinin seleksiyonu. Adnan Menderes Üniversitesi Ziraat Fakültesi Dergisi, 4(1-2), 39 48.

Zerbini, E., \& Polesollo, A. (1984). Measuring the color of apple skin by two diffirent techniques. Proceeding of the Workshop on Pome-Fruit Quality, 1, 161-171. 